\title{
Postoperation of cervical cancer with intestine metastasis: a case report and literature review
}

\author{
Xiuyan $\mathrm{Yu}^{1,2+}$, Zhen Wang ${ }^{1,2+}$, Zhigang Zhang ${ }^{3}$, Yang Liü ${ }^{3}$ and Jian Huang ${ }^{1,2^{*}}$
}

\begin{abstract}
Background: Cervical cancer can infiltrate locally and directly spread to adjacent organs including the vagina, peritoneum, urinary bladder, ureters, rectum, and paracervical tissue, but the intestine metastasis from cervical cancer is extremely rare, which can easily be misdiagnosed.

Case presentation: Here, we report a case about a 45-year-old postoperative cervical cancer patient with metastases to small intestine and sigmoid colon who presented abdominal distention and dull pain due to intestinal obstruction. The patient underwent exploratory laparotomy, and two intestinal segments including the tumors were resected. The postoperative pathological diagnosis illustrated sigmoid colon and terminal ileum metastatic squamous cell carcinoma.

Conclusions: This case demonstrates that intestine metastasis must be considered in the differential diagnosis of acute abdomen in patients with cervical cancer even at an early tumor stage.
\end{abstract}

Keywords: Intestinal obstruction, Cervical cancer, Metastasis, Ileum, Sigmoid colon

\section{Background}

Cervical cancer is a worldwide disease which ranks as the second most common malignant disease and also the third most common cause of cancer death among women [1]. More than $90 \%$ of cases are attributed to human papillomavirus (HPV) infection [2]. Most cases occur in developing countries, as no effective screening procedures are available [3]. Over the past decades, the survival of patients with cervical carcinoma has significantly improved attributing to early screening and the rapid development of concurrent cisplatin-based chemotherapy and radiotherapy $[4,5]$. In spite of the prolonged survival, the patients are

\footnotetext{
* Correspondence: drhuangjian@zju.edu.cn

${ }^{\dagger}$ Equal contributors

'Cancer Institute (Key Laboratory of Cancer Prevention and Intervention, China National Ministry of Education, Key Laboratory of Molecular Biology in Medical Sciences, Zhejiang Province, China), The Second Affiliated Hospital, Zhejiang University School of Medicine, 88 Jiefang Road, Hangzhou, Zhejiang Province 310009, China

2Department of Surgical Oncology, The Second Affiliated Hospital, Zhejiang University School of Medicine, 88 Jiefang Road, Hangzhou, Zhejiang Province 310009, China

Full list of author information is available at the end of the article
}

also at an increased risk of recurrence and metastases, which are the main causes of death. The primary routes in cervical carcinoma metastases are direct local extension and lymphatic dissemination, while hematogenous dissemination occurs infrequently, which usually occurs with advanced tumor or uncommon pathologic types, such as adenosquamous or neuroendocrine tumors. In general, cervical cancer can spread to adjacent organs including the vagina, peritoneum, urinary bladder, ureters, rectum, and paracervical tissue. Meanwhile, Common distant metastatic sites include the lungs, bones, and liver [6], but cervical cancer metastases to the small intestine and sigmoid colon are rare. Here, we present the first reported case of a cervical cancer patient with simultaneous metastases to the small intestine and sigmoid colon, based on our knowledge.

\section{Case presentation}

A 45-year-old woman was admitted to our department with a 5-day history of abdominal distention and dull pain, especially at the upper umbilical region, and vomiting of gastric content without 

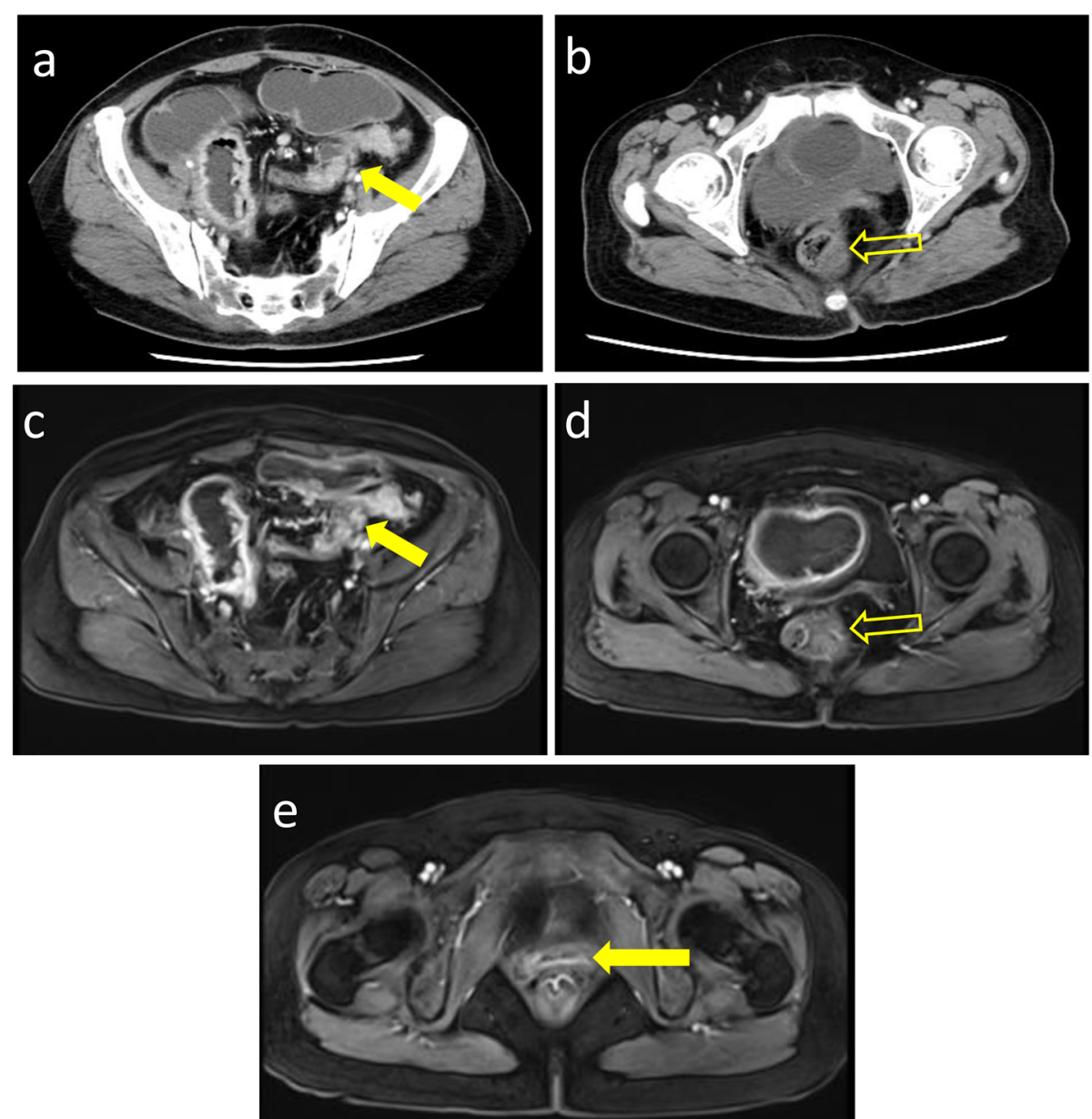

Fig. 1 Abdominal computed tomography $(C T)$ scan. CT scan revealed lower intestinal obstruction with a thickened bowel wall in the terminal ileum (solid yellow arrow in (a) and upper sigmoid colon (feint yellow arrow in (b). Abdominal magnetic resonance (MR) revealed a thickened bowel wall in the terminal ileum (solid yellow arrow in (c) and upper sigmoid colon (feint yellow arrow in $\mathbf{d}$ ). MR imaging also showed an unremarkable uterus stump (solid yellow arrow in e)

passage of stools or flatus. She had an erect abdominal plain radiograph which showed intestinal obstruction in a local hospital previously.

A careful medical history was taken on admission. Three years ago, she suffered from cervical cancer and had a radical hysterectomy with adnexectomy. The postoperative pathological diagnosis is cervical moderately differentiated squamous cell carcinoma with its maximum diameter to $9 \mathrm{~mm}$ and infiltration depth to $2 \mathrm{~mm}$. No lymph node metastasis was found in the bilateral pelvic and common iliac lymph node. It was diagnosed with International Federation of Gynecology and Obstetrics (FIGO) stage IB1 cervical cancer. After the operation, she had a 3- to 6-month follow-up but did not have any radiotherapy or chemotherapy.

On physical examination, her vital signs were stable. There were no lesions in the oropharynx and nasopharynx. She had abdominal light distension and a loud gurgling sound. No abdominal tenderness and rebound tenderness were found. Rectal examination and bimanual vaginal examination had no obvious abnormalities including lump and bleeding. Analysis of blood tests was unremarkable except the elevating of squamous cell carcinoma antigen (SCCA) and CA125. An erect abdominal plain radiograph was rechecked, showing the upper left intestine expanding and fluid levels with a stepladder pattern. Abdominal contrasted computed tomography (CT) showed intestinal obstruction with a thickened bowel wall in the terminal ileum and upper sigmoid colon (Fig. 1a, b). Abdominal magnetic resonance imaging (MRI) indicated the same result (Fig. 1c, d) and an unremarkable uterus stump (Fig. 1e). Colonoscopy showed a narrowed sigmoid colon lumen with smooth mucosa, and the pathological results indicated mucosal chronic 


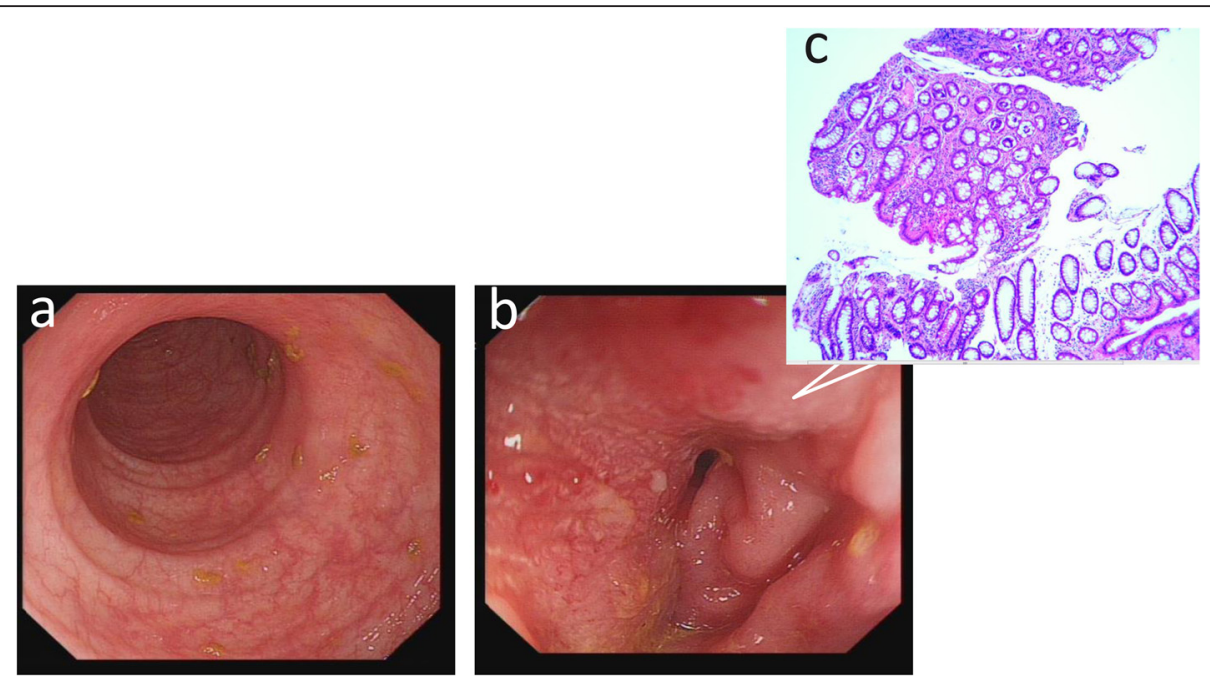

Fig. 2 Colonoscopy and biopsy. Colonoscopy confirmed that the intestinal mucosa was smooth without ulcers or lumps (a) except sigmoid colon luminal narrowing (b). Pathology result of the narrowing site biopsy showed mucosal chronic inflammation (c)

inflammation (Fig. 2). Chest CT and X-ray had no obvious abnormity.

The patient was fasted and received passive gastric decompression along with total parenteral nutrition on admission. Abdominal distention eased on the first day. In consideration of the patient's condition and the imaging examination and colonoscopy results, exploratory laparotomy was performed. Widespread intestinal adhesion and two firm tumors $(2 * 2 \mathrm{~cm}$ and 3*2 $\mathrm{cm}$ separately) with a local thickened intestine wall at the end of the ileum and upper sigmoid colon were noted. She underwent segmental intestine resection and had end-to-end anastomosis. The postoperative pathological diagnosis showed squamous cell carcinoma (Fig. 3). After the operation, up until now (4 months), the patient has been treated with four cycles of a docetaxel-cisplatin combination chemotherapy regimen (day $1,75 \mathrm{mg} / \mathrm{m}^{2}$ docetaxel; days $1-3$, $25 \mathrm{mg} / \mathrm{m}^{2}$ cisplatin, per 21 days).

\section{Discussion}

In the present case, the patient underwent segmental intestine resection, and the pathological result indicated squamous cell carcinoma. Excluding possible primary lesions like oropharynx, nasopharynx, lung, and esophagus cancer, with the characteristics of outside-to-inside invasion from the pathology result, indicating the primary lesion in the abdominal or pelvic cavity, cervical cancer
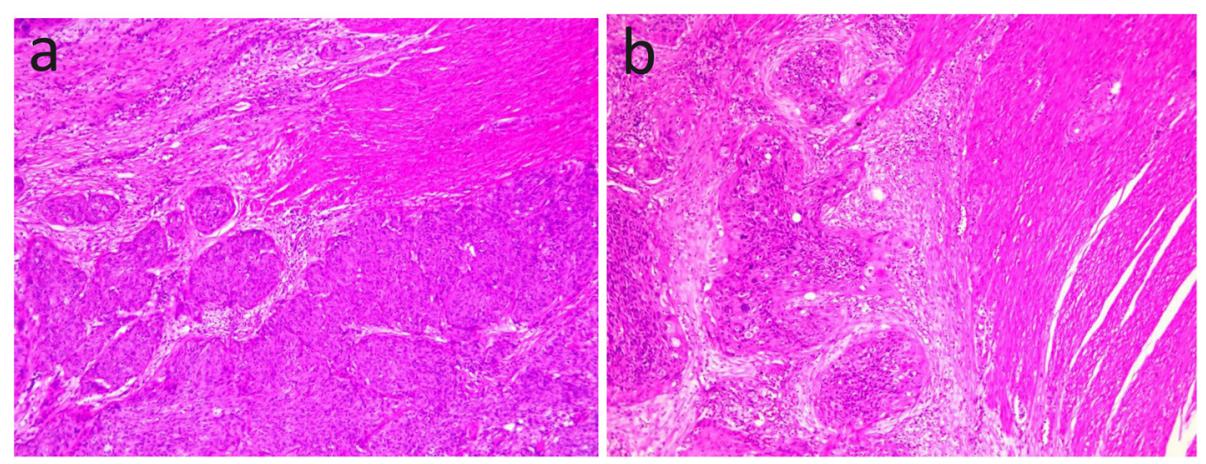

Fig. 3 Postoperative pathological examination. Microscopic examination of the intestinal tumor demonstrated a full-thickness wall of sigmoid colon and serosa, and the muscular layer of the terminal ileum had metastatic squamous cell carcinoma. Cancer embolus was seen in the vessel, and the peri-intestine lymph node also had metastatic squamous cell carcinoma. a small intestine and $\mathbf{b}$ sigmoid colon (staining with hematoxylin and eosin, $\times 100$ magnification) 
Table 1 The main metastatic sites of cervical cancer

\begin{tabular}{ll}
\hline metastatic sites $^{\text {a }}$ [26] & Percent \\
\hline Nodes & 8.6 \\
Supraclavicular & 3.0 \\
Para-aortic & 3.0 \\
Inguinal & 2.3 \\
Mediastinal & 1.7 \\
Iliac & 1.3 \\
Cervical & 0.8 \\
Axillary & 0.5 \\
Other & 1.8 \\
Lung & 5.7 \\
Bone & 3.8 \\
Peritoneum & 0.6 \\
Liver & 2.2 \\
Gastrointestinal tract & 8.0 \\
Stomach [17] & $<2.0$ \\
Ileum [27] & $1.2-3.2$ \\
Spleen [28] & $1.6-30.0$ \\
Ovary [29] & $1.3-6.3$ \\
Heart [30] & 1.2 \\
Brain [31] & $0.4-1.2$ \\
Skin and subcutaneous tissue [32] & $0.1-2.0$ \\
\hline aModified and updated from [26] &
\end{tabular}

${ }^{\mathrm{a}}$ Modified and updated from [26]

with small intestine and sigmoid colon metastases was diagnosed.

After precise calculation, the 10-year incidence of distant metastases was $3 \%$ for stage IA, $16 \%$ for stage IB, $31 \%$ for stage IIA, $26 \%$ for stage IIB, $39 \%$ for stage III, and $75 \%$ for stage IVA in cervical cancer patients [7]. The most frequently observed metastatic sites were the lungs, bones, liver, supraclavicular nodes, and para-aortic nodes etc. (Table 1). Unusual metastases can be seen in the skin and soft tissues [8], breast [9], pericardium [10], umbilical region [11], labia and introitus area [12], thyroid gland [13], oral cavity [14], and skeletal muscle [15]. Cervical cancer metastatic to the intestine is a rare occurrence. Table 2 provides a comprehensive review of the published cases of intestine metastases from cervical cancer in the English literature dating back to 1976. Things did not go the way we thought because not only do cervical cancer metastases to the intestine occur at an advanced tumor stage, but they also occur at an early stage, even at stage IA. The case presented here is the first report of cervical cancer with simultaneous small intestine and sigmoid colon metastases.
The intestine metastases usually occur through the lymphatics to the bowel serosa and less commonly via intraperitoneal dissemination, direct spread, and hematogenous spread [16-18]. As for the present case, another explanation is surgical factor, for tumor dissemination may be caused by reckless operation. Although the possible metastatic route is distinct, the rarity of intestine metastases is still unclear now [19]. Sigmoid colon metastases are rarely seen and may be because of the relatively short intestinal segment. While small intestine accounted for a large space in the enterocelia. So, the low incidence rates of small intestine metastases are notable, and several associated mechanisms have been raised as follows [20-24]: (1) the intestine has abundant immune protection with numerous lymphoid cells and large secretions of IgA in the mucosa and submucosa of the intestine; (2) a rapid refresh rate of small intestinal mucosa may inhibit the tumorigenesis; (3) liquefied chyme may cause less mucosal irritation, then reduces mechanical injury and inflammation [19].

In general, a small intestine and sigmoid colon metastatic tumor indicates a poor prognosis. Bleeding and obstruction, as well as non-specific symptoms such as abdominal discomfort, gas distension, and vomiting, are common clinical features. Some reasons may cause a misdiagnosis and delay the treatment: (1) non-specific gastrointestinal symptoms may easily be seen as a symptom of tumor progression or adverse drug reaction; (2) lack of awareness of metastatic tumor; (3) ordinary CT scanners cannot find minimal lesions, especially in the small intestine. Once intestine metastasis is suspected, contrast-enhanced CT, endoscope, and even exploratory laparotomy should be operated. Typical features of intestinal metastases include intestinal wall thickening and stiffness, submucosal spread, and ulcers. Typically, metastases are submucosal or subserosal, which make the primary and secondary tumors easily distinguishable; besides, cytokeratin immunohistochemistry may help to differentiate the two. Metastatic cervical carcinoma is usually positive for CK7, epithelial membrane antigen, and CK5/6 and negative for CK20 [25]. The treatment for a small intestine and sigmoid colon metastatic tumor from cervical squamous cell carcinoma remains debatable because of the lack of enough cases to compare the efficacy of different treatments. Laparotomy seems to be the common choice if the patients are physically capable (Table 2). Chemotherapy could also be employed as a palliative treatment.

\section{Conclusions}

This report presents a rare case of small intestine and sigmoid colon metastases of cervical cancer that caused 
Table 2 Intestine metastases from cervical cancer as reported in the literature

\begin{tabular}{|c|c|c|c|c|c|c|c|c|c|c|c|c|}
\hline No. & Author [Ref.] & Year & Age & Pathologic type & $\begin{array}{l}\text { Stage of } \\
\text { SCCA of } \\
\text { cervix at } \\
\text { diagnosis }\end{array}$ & Previous treatment & Interval time & Symptom & Metastasis sites & $\begin{array}{l}\text { Confirmation } \\
\text { of diagnosis }\end{array}$ & Treatment & Outcome \\
\hline 1 & $\begin{array}{l}\text { Bradley Watson } \\
\text { [27] }\end{array}$ & 1976 & 47 & $\begin{array}{l}\text { Adenosquamous } \\
\text { carcinoma }\end{array}$ & Stage IV & None & Synchronous & $\begin{array}{l}\text { Intermittent central } \\
\text { abdominal pain } \\
\text { associated with vomiting }\end{array}$ & Small intestine & Laparotomy & $\begin{array}{l}\text { Segmentary } \\
\text { intestinal } \\
\text { resection }\end{array}$ & NA \\
\hline 2 & Gurian, L. [17] & 1981 & 64 & $\begin{array}{l}\text { Squamous cell } \\
\text { carcinoma }\end{array}$ & Stage IIIB & None & Synchronous & Occult bleeding & Duodenum & Endoscopy & $\begin{array}{l}\text { Refused } \\
\text { surgical } \\
\text { intervention }\end{array}$ & Death \\
\hline 3 & $\begin{array}{l}\text { Mathur, S. K. } \\
{[18]}\end{array}$ & 1984 & 35 & $\begin{array}{l}\text { Squamous cell } \\
\text { carcinoma }\end{array}$ & Stage IV & None & Synchronous & $\begin{array}{l}\text { Central abdominal } \\
\text { angina, persistent } \\
\text { vomiting and constipation }\end{array}$ & Terminal ileum & Laparotomy & $\begin{array}{l}\text { Right } \\
\text { hemicolectomy }\end{array}$ & Recovery \\
\hline 4 & $\begin{array}{l}\text { Christopherson, } \\
\text { W. [33] }\end{array}$ & 1985 & 42 & $\begin{array}{l}\text { Squamous cell } \\
\text { carcinoma }\end{array}$ & Stage IIIB & NA & 2 years & $\begin{array}{l}\text { Intermittent nausea } \\
\text { and vomiting, upper } \\
\text { abdominal pain }\end{array}$ & $\begin{array}{l}\text { lleum, } \\
\text { transverse colon }\end{array}$ & Laparotomy & $\begin{array}{l}\text { Segmentary } \\
\text { intestinal } \\
\text { resection }\end{array}$ & Recovery \\
\hline 5 & $\begin{array}{l}\text { Hulecki, S. J. } \\
{[34]}\end{array}$ & 1985 & 48 & $\begin{array}{l}\text { Squamous cell } \\
\text { carcinoma }\end{array}$ & Stage IB & NA & 7 years & $\begin{array}{l}\text { Gross hematuria from the } \\
\text { conduit }\end{array}$ & Ileum & Endoscopy & Laparotomy & Recovery \\
\hline 6 & Misonou, J. [16] & 1988 & 69 & $\begin{array}{l}\text { Squamous cell } \\
\text { carcinoma }\end{array}$ & Stage IA & Hysterectomy & 13 years & $\begin{array}{l}\text { Sudden onset of } \\
\text { pan-peritonitis }\end{array}$ & Small intestine & NA & NA & NA \\
\hline 7 & Singla, M. [35] & 2011 & 48 & $\begin{array}{l}\text { Squamous cell } \\
\text { carcinoma }\end{array}$ & NA & Radiation therapy & 2 years & $\begin{array}{l}\text { Right hypochondrium } \\
\text { pain }\end{array}$ & $\begin{array}{l}\text { Hepatic flexure } \\
\text { of colon }\end{array}$ & Laparotomy & $\begin{array}{l}\text { Right extended } \\
\text { hemicolectomy }\end{array}$ & $\begin{array}{l}\text { Recovery } \\
\text { for } 2 \text { years }\end{array}$ \\
\hline 8 & Kanthan, R. [19] & 2011 & 49 & $\begin{array}{l}\text { Squamous cell } \\
\text { carcinoma }\end{array}$ & Stage IIA & $\begin{array}{l}\text { Chemotherapy and } \\
\text { radiation treatment }\end{array}$ & 2 years & $\begin{array}{l}\text { Upper-gastrointestinal } \\
\text { bleeding }\end{array}$ & Duodenum & $\begin{array}{l}\text { esophagogastro } \\
\text { duodenoscopy }\end{array}$ & None & $\begin{array}{l}\text { Died of } \\
\text { multiple } \\
\text { organ } \\
\text { failure }\end{array}$ \\
\hline 9 & Lee T.H. [36] & 2011 & 50 & $\begin{array}{l}\text { Squamous cell } \\
\text { carcinoma }\end{array}$ & Stage $\| \mathrm{A}$ & $\begin{array}{l}\text { Hysterectomy with } \\
\text { systemic } \\
\text { chemotherapy }\end{array}$ & 2 years & Epigastric pain & $\begin{array}{l}\text { Ampulla of } \\
\text { vater }\end{array}$ & Endoscopy & Chemotherapy & NA \\
\hline 10 & $\begin{array}{l}\text { Raphael, J. C. } \\
\text { [37] }\end{array}$ & 2011 & 57 & $\begin{array}{l}\text { Squamous cell } \\
\text { carcinoma }\end{array}$ & Stage IV & None & Synchronous & $\begin{array}{l}\text { Persistent epigastric pain } \\
\text { and vomiting }\end{array}$ & $\begin{array}{l}\text { Pyloroduodenal } \\
\text { region }\end{array}$ & Endoscopy & chemotherapy & NA \\
\hline 11 & $\begin{array}{l}\text { Sugimoto, } \mathrm{T} \text {. } \\
\text { [38] }\end{array}$ & 2013 & 84 & Adenocarcinoma & Stage III & Radiation therapy & 3 months & Epigastric pain & Ileum & Laparotomy & $\begin{array}{l}\text { The necrotic } \\
\text { part of the } \\
\text { ileum resection }\end{array}$ & $\begin{array}{l}4 \text { months } \\
\text { survival }\end{array}$ \\
\hline 12 & Joshi, S. R. [39] & 2013 & 50 & $\begin{array}{l}\text { Squamous cell } \\
\text { carcinoma }\end{array}$ & Stage II & $\begin{array}{l}\text { Wertheim's } \\
\text { hysterectomy }\end{array}$ & 5 months & $\begin{array}{l}\text { Abdominal pain, vomiting } \\
\text { and intermittent fever }\end{array}$ & $\begin{array}{l}\text { Ileocaecal } \\
\text { region }\end{array}$ & Laparotomy & $\begin{array}{l}\text { Segmentary } \\
\text { intestinal } \\
\text { resection }\end{array}$ & NA \\
\hline 13 & Datta, S. [40] & 2013 & 55 & $\begin{array}{l}\text { Squamous cell } \\
\text { carcinoma }\end{array}$ & Stage IIB & Chemoradiation & 3.5 years & $\begin{array}{l}\text { Abdominal pain, } \\
\text { vomiting, constipation }\end{array}$ & $\begin{array}{l}\text { lleocaecal } \\
\text { region }\end{array}$ & Laparotomy & $\begin{array}{l}\text { Right } \\
\text { hemicolectomy }\end{array}$ & NA \\
\hline 14 & Barlin, J. N. [41] & 2013 & 37 & $\begin{array}{l}\text { Adenosquamous } \\
\text { carcinoma }\end{array}$ & Stage IB & $\begin{array}{l}\text { Radical } \\
\text { hysterectomy }\end{array}$ & 1.5 years & Hematochezia & Sigmoid colon & Colonoscopy & $\begin{array}{l}\text { Rectosigmoid } \\
\text { resection }\end{array}$ & Recovery \\
\hline 15 & Iliescu, L. [42] & 2014 & 70 & $\begin{array}{l}\text { Squamous cell } \\
\text { carcinoma }\end{array}$ & Stage IIA1 & $\begin{array}{l}\text { Radiation therapy } \\
\text { followed by } \\
\text { curative surgery }\end{array}$ & 2 years & $\begin{array}{l}\text { Intermittent subocclusive } \\
\text { symptoms, fatigue, } \\
\text { nausea }\end{array}$ & Terminal ileum & Laparotomy & $\begin{array}{l}\text { Segmentary } \\
\text { intestinal } \\
\text { resection }\end{array}$ & NA \\
\hline
\end{tabular}


Table 2 Intestine metastases from cervical cancer as reported in the literature (Continued)

\begin{tabular}{|c|c|c|c|c|c|c|c|c|c|c|c|c|}
\hline 16 & Debasish, B. [43] & 2014 & 43 & $\begin{array}{l}\text { Squamous cell } \\
\text { carcinoma }\end{array}$ & NA & $\begin{array}{l}\text { Total abdominal } \\
\text { hysterectomy }\end{array}$ & 8 months & $\begin{array}{l}\text { Symptoms of chronic } \\
\text { intestinal obstruction }\end{array}$ & Terminal ileum & Laparotomy & $\begin{array}{l}\text { Right } \\
\text { hemicolectomy }\end{array}$ & NA \\
\hline 17 & $\begin{array}{l}\text { Nagarekha, K. } \\
\text { [44] }\end{array}$ & 2014 & 50 & $\begin{array}{l}\text { Squamous cell } \\
\text { carcinoma }\end{array}$ & NA & $\begin{array}{l}\text { Hysterectomy with } \\
\text { bilateral salpingo- } \\
\text { oophorectomy }\end{array}$ & 3 months & $\begin{array}{l}\text { Vomiting and abdominal } \\
\text { pain }\end{array}$ & Jejunum & Laparotomy & $\begin{array}{l}\text { Segmentary } \\
\text { intestinal } \\
\text { resection }\end{array}$ & NA \\
\hline 18 & Hui Qiu [45] & 2015 & 46 & $\begin{array}{l}\text { Squamous cell } \\
\text { carcinoma }\end{array}$ & Stage IIB & Chemoradiotherapy & 4 years & Acute abdominal pain & $\begin{array}{l}\text { Ileocaecal } \\
\text { region }\end{array}$ & Laparotomy & $\begin{array}{l}\text { Segmentary } \\
\text { intestinal } \\
\text { resection }\end{array}$ & $\begin{array}{l}\text { Recovery } \\
\text { for } 2 \text { years }\end{array}$ \\
\hline
\end{tabular}

NA not available from original literature 
obstruction. Clinicians should be aware that intestine metastasis must be considered in the differential diagnosis of acute abdomen in patients with cervical cancer even at an early tumor stage.

\section{Consent}

Written informed consent was obtained from the patient for publication of this Case report and any accompanying images. This report adhered to the tenets of the Declaration of Helsinki.

\section{Abbreviations}

CT: computed tomography; FIGO: International Federation of Gynecology and Obstetrics; MRI: magnetic resonance imaging; SCCA: squamous cell carcinoma antigen.

\section{Competing interests}

The authors declare that they have no competing interests.

\section{Authors' contributions}

$\mathrm{XY}$ and $\mathrm{ZW}$ contributed equally to the manuscript. $J \mathrm{H}$ is the corresponding author of the manuscript. XY participated in the design of the study. ZW reviewed the literature. $Z Z$ collected the patient's data and provided the figures. $X Y, Z W, Y L$ were involved in drafting the manuscript. JH revised the manuscript. All authors read and approved the final manuscript.

\section{Acknowledgements}

The authors would like to thank the members of the group for useful discussions and Dr. Dang Wu for language assistance.

The work was supported by grants from the Zhejiang Provincial Natural Science Foundation of China (No. Y15H160095). Written consent was obtained from the patient for publication of the study.

\begin{abstract}
Author details
${ }^{1}$ Cancer Institute (Key Laboratory of Cancer Prevention and Intervention, China National Ministry of Education, Key Laboratory of Molecular Biology in Medical Sciences, Zhejiang Province, China), The Second Affiliated Hospital, Zhejiang University School of Medicine, 88 Jiefang Road, Hangzhou, Zhejiang Province 310009, China. ${ }^{2}$ Department of Surgical Oncology, The Second Affiliated Hospital, Zhejiang University School of Medicine, 88 Jiefang Road, Hangzhou, Zhejiang Province 310009, China. ${ }^{3}$ Department of Gynecology, The Second Affiliated Hospital, Zhejiang University School of Medicine, 88 Jiefang Road, Hangzhou, Zhejiang Province 310009, China.
\end{abstract}

Received: 8 September 2015 Accepted: 30 December 2015 Published online: 06 January 2016

\section{References}

1. Siegel RL, Miller KD, Jemal A. Cancer statistics, 2015. CA Cancer J Clin. 2015; 65:5-29.

2. Schiffman M, Castle PE, Jeronimo J, Rodriguez AC, Wacholder S. Human papillomavirus and cervical cancer. Lancet. 2007;370:890-907.

3. Waggoner SE. Cervical cancer. Lancet. 2003;361:2217-25.

4. Mountzios G, Soultati A, Pectasides D, Pectasides E, Dimopoulos MA, Papadimitriou CA. Developments in the systemic treatment of metastatic cervical cancer. Cancer Treat Rev. 2013;39:430-43.

5. Chao A, Lin CT, Lai CH. Updates in systemic treatment for metastatic cervical cancer. Curr Treat Options Oncol. 2014;15:1-13.

6. Nartthanarung A, Thanapprapasr K, Udomsubpayakul U, Thanapprapasr D. Age and survival of cervical cancer patients with bone metastasis. Asian Pac J Cancer Prev. 2014;15:8401-4.

7. Fagundes H, Perez CA, Grigsby PW, Lockett MA. Distant metastases after irradiation alone in carcinoma of the uterine cervix. Int J Radiat Oncol Biol Phys. 1992;24:197-204.

8. Mehrotra S, Singh U, Gupta HP, Saxena P. Cutaneous metastasis from cervical carcinoma: an ominous prognostic sign. J Obstet Gynaecol. 2010;30:78-9.
9. Aitelhaj M, Khoyaali SL, Boukir A, Elkabous M, Abahssain H, Mrabti H, et al. Breast and splenic metastases of squamous cell carcinoma from the uterine cervix: a case report. J Med Case Rep. 2014;8:359.

10. Kim HS, Park NH, Kang SB. Rare metastases of recurrent cervical cancer to the pericardium and abdominal muscle. Arch Gynecol Obstet. 2008;278: 479-82.

11. Behtash N, Mehrdad N, Shamshirsaz A, Hashemi R, Amouzegar Hashemi F. Umblical metastasis in cervical cancer. Arch Gynecol Obstet. 2008;278:489-91.

12. Richmond NA, Viera MH, Velazquez-Vega J, Kerdel FA. Cutaneous metastasis of cervical adenocarcinoma to the vulva. Dermatol Online J. 2013;19:18172.

13. Karapanagiotou E, Saif MW, Rondoyianni D, Markaki S, Alamara C, Kiagia M, et al. Metastatic cervical carcinoma to the thyroid gland: a case report and review of the literature. Yale J Biol Med. 2006:79:165-8.

14. Ram H, Kumar M, Bhatt ML, Shadab M: Oral metastases from carcinoma of cervix. BMJ Case Rep 2013, 2013. doi: 10.1136/bcr-2013-010020

15. Ferrandina G, Salutari V, Testa A, Zannoni GF, Petrillo M, Scambia G. Recurrence in skeletal muscle from squamous cell carcinoma of the uterine cervix: a case report and review of the literature. BMC Cancer. 2006;6:169.

16. Misonou J, Natori T, Aizawa M, Jou B, Tamaki A, Ogasawara M. Stage (la) cervical cancer recurring 13 years after hysterectomy and causing small intestinal perforation. A case report with a review of the literature. Acta Pathol Jpn. 1988;38:225-34.

17. Gurian L, Ireland K, Petty W, Katon R. Carcinoma of the cervix involving the duodenum: case report and review of the literature. J Clin Gastroenterol. 1981;3:291-4

18. Mathur SK, Pandya GP. Solitary metastatic malignant stricture of the ileum: a rare cause of small bowel obstruction (a case report). J Postgrad Med. 1984; 30:186-8.

19. Kanthan R, Senger JL, Diudea D, Kanthan S. A review of duodenal metastases from squamous cell carcinoma of the cervix presenting as an upper gastrointestinal bleed. World J Surg Oncol. 2011;9:113.

20. Schottenfeld D, Beebe-Dimmer JL, Vigneau FD. The epidemiology and pathogenesis of neoplasia in the small intestine. Ann Epidemiol. 2009; 19:58-69.

21. Torres M, Matta E, Chinea B, Dueno MI, Martinez-Souss J, Ojeda A, et al. Malignant tumors of the small intestine. J Clin Gastroenterol. 2003;37: 372-80.

22. Loualidi A, Spooren PF, Grubben MJ, Blomjous CE, Goey SH. Duodenal metastasis: an uncommon cause of occult small intestinal bleeding. Neth J Med. 2004;62:201-5.

23. Kariv R, Arber N. Malignant tumors of the small intestine-new insights into a rare disease. Isr Med Assoc J. 2003;5:188-92.

24. Calman KC. Why are small bowel tumours rare? An experimental model. Gut. 1974;15:552-4.

25. Berezowski K, Stastny JF, Kornstein MJ. Cytokeratins 7 and 20 and carcinoembryonic antigen in ovarian and colonic carcinoma. Mod Pathol. 1996:9:426-9.

26. Carlson V, Delclos L, Fletcher GH. Distant metastases in squamous-cell carcinoma of the uterine cervix. Radiology. 1967;88:961-6.

27. Bradley-Watson PJ, Leiman G. Ileal metastasis in cervical carcinoma: a case report. S Afr Med J. 1976:50:1937-8.

28. Goktolga U, Dede M, Deveci G, Yenen MC, Deveci MS, Dilek S. Solitary splenic metastasis of squamous cell carcinoma of the uterine cervix: a case report and review of the literature. Eur J Gynaecol Oncol. 2004;25:742-4.

29. Nakanishi T, Wakai K, Ishikawa H, Nawa A, Suzuki Y, Nakamura S, et al. A comparison of ovarian metastasis between squamous cell carcinoma and adenocarcinoma of the uterine cervix. Gynecol Oncol. 2001;82:504-9.

30. Grigsby PW. The prognostic value of PET and PET/CT in cervical cancer. Cancer Imaging. 2008;8:146-55

31. Park SH, Ro DY, Park BJ, Kim YW, Kim TE, Jung JK, et al. Brain metastasis from uterine cervical cancer. J Obstet Gynaecol Res. 2010;36:701-4.

32. Basu B, Mukherjee S. Cutaneous metastasis in cancer of the uterine cervix: a case report and review of the literature. J Turk Ger Gynecol Assoc. 2013;14:174-7

33. Christopherson W, Voet R, Buchsbaum HJ. Recurrent cervical cancer presenting as small bowel obstruction. Gynecol Oncol. 1985;22:109-14.

34. Hulecki SJ, Klein FA, Davis JE. Squamous cell carcinoma of cervix metastatic to ileal loop. Urology. 1985;26:579-80.

35. Singla M, Singal R, Singla S, Sahu P, Kaur S, Goyal YR. Isolated metastasis to colon from carcinoma cervix. Indian J Cancer. 2011;48:267-8. 
36. Lee TH, Park SH, Lee CK, Lee SH, Chung IK, Kim SJ, et al. Ampulla of Vater metastasis from recurrent uterine cervix carcinoma presenting as groove pancreatitis. Gastrointest Endosc. 2011;73:362-3.

37. Raphael JC, Ram TS, Pavamani S, Choudharie L, Viswanathan PN. Squamous cell carcinoma cervix with metastasis to pyloroduodenal region. J Cancer Res Ther. 2011;7:183-4.

38. Sugimoto T, Mike M, Abe M, Kano N. Small bowel metastasis of uterine cervical adenocarcinoma. BMJ Case Rep. 2013;2013:007896.

39. Joshi Sneha R, Tekwani Deepa T, Mangala N. Bowel metastasis from carcinoma cervix: a rare case report. IJBAMR. 2013;2:1061-4.

40. Datta SBU, Khatua S, Nigam M. Metastasis from cervical carcinoma presenting with acute intestinal obstruction - a case report. Bangladesh J Med Sci. 2013;12:439-41.

41. Barlin JN, Kim JS, Barakat RR. Recurrent cervical cancer isolated to the sigmoid colon: a case report. Gynecol Oncol Case Rep. 2013:6:28-30.

42. Iliescu L, David L, Orban C, Herlea V, Toma L. A rare case of ileal metastasis from cervical cancer. Chirurgia (Bucur). 2014;109:390-2.

43. Debasish Bhattacharya SK, Abhijit B. A rare cause of intestinal obstruction: ileal squamous cell carcinoma - a case report. Int J Recent Trends Sci Technol. 2014;13:260-1.

44. Kulkarni N. Squamous cell carcinoma of the cervix metastasis to the jejunum - a rare case report. World J Pathol. 2014;4:2.

45. Qiu H, Yuan L, Ou Y, Zhu Y, Xie C, Zhang G. Small intestine metastasis from cervical cancer with acute abdomen: a case report. Oncol Lett. 2015;9:187-90.

\section{Submit your next manuscript to BioMed Central and we will help you at every step:}

- We accept pre-submission inquiries

- Our selector tool helps you to find the most relevant journal

- We provide round the clock customer support

- Convenient online submission

- Thorough peer review

- Inclusion in PubMed and all major indexing services

- Maximum visibility for your research

Submit your manuscript at www.biomedcentral.com/submit

C Biomed Central 